\title{
Significance of bacterial biomass in lakes and the ocean: comparison to phytoplankton biomass and biogeochemical implications
}

\author{
Meinhard Simon ${ }^{1}$, Byung C. Cho ${ }^{2}$, Farooq Azam ${ }^{3}$ \\ ${ }^{1}$ Limnological Institute, University of Constance, PO Box 5560, W-7750 Konstanz, Germany \\ ${ }^{2}$ Department of Environmental Sciences, Hankuk University of Foreign Studies, Young-in Gun, Kyung-gi Do, \\ Republic of Korea 449-791 \\ ${ }^{3}$ Marine Biological Research Division, Scripps Institution of Oceanography A-002, University of California San Diego, \\ La Jolla, California 92093, USA
}

\begin{abstract}
We have synthesized the information on marine and limnetic bacterial biomass carbon $(\mathrm{BOC})$ and phytoplankton biomass carbon (PhytoC) to examine the relationships between these major biotic carbon pools. On the basis of 6 limnetic and 6 marine studies we found a good similarity for the correlations of BOC vs PhytoC in both systems although the slope was substantially lower than for similar correlations on the basis of bacterial abundance and chlorophyll $a$. Limnetic systems, however, differed from marine systems in that they supported more BOC relative to PhytoC, as indicated by significantly higher $y$-intercepts of the correlation $(\mathrm{p}<0.001)$. Our analysis also generalizes findings from marine to limnetic environments that the food-web structure in oligotrophic systems is fundamentally different from eutrophic systems, e.g. that BOC/PhytoC dramatically increases with decreasing PhytoC concentrations. This has implications for the significance of planktonic bacteria in particle abundance and size-dependent properties of lakes and oceans such as trace metal and radionuclide adsorption, biogeochemical dynamics and in light scattering and remote sensing.
\end{abstract}

\section{INTRODUCTION}

The flux, cycling and sedimentation of elements and energy are key processes in pelagic ecosystems and have been studied extensively during the past $20 \mathrm{yr}$ in marine and limnetic environments. Heterotrophic planktonic bacteria have been found to be an important component of these ecosystems. Their production often equals $20 \%$ of planktonic primary production (Cole et al. 1988) and their carbon demand can be equivalent to 40 to $60 \%$ of phytoplankton carbon fixation. It is well established that marine and limnetic ecosystems exhibit differences in their physical, chemical, and foodweb structure although they also share common features. Pelagic limnetic systems usually are more closed systems in which water movements are less pronounced than in the ocean but allochthonous sources are more important for nutrient inputs than in marine pelagic systems (Hobbie 1988). The species composition of marine and freshwater phytoplankton, for instance, shows pronounced differences although the ecological role in the 2 types of systems is similar (Kilham \& Hecky 1988, but see Baines \& Pace 1991). Whereas the growth of marine phytoplankton usually is N-limited, limnetic phytoplankton are usually Plimited (Hecky \& Kilham 1988) although exceptions occur in marine environments (Krom et al. 1992) as well as in lakes (see references in Dodds et al. 1991). This may lead to some differences in the relation between photosynthesis and extracellular release of photosynthetic products between these systems (Baines \& Pace 1991). The species diversity of marine metazooplankton is much greater than that of limnetic zooplankton. For example, mucus-feeders are not represented among the limnetic zooplankton. On the other hand, limnetic crustacean zooplankton comprise relatively more cladocerans than copepods which dominate in marine waters (Lehman 1988). The proto- 
zooplankton as the major consumers of bacterial production in lakes and the ocean appear to be fairly comparable in both environments although distinct features are not well studied (Hobbie 1988, Lehman 1988, Weisse 1991). Also the ecological role of planktonic bacteria in both ecosystems appears to be comparable despite structural and physiological differences (Hobbie 1988).

In eutrophic marine and limnetic ecosystems, bacterial biomass carbon (BOC) has been found to typically comprise 3 to $20 \%$ of total microbial biomass (e.g. Fuhrman et al. 1980, Schleyer 1981, Pedrós-Alió \& Brock 1982, Riemann et al. 1982, Holligan et al. 1984). In meso- to oligotrophic marine and limnetic environments $\mathrm{BOC}$ comprises the major fraction of particulate organic carbon (POC; Simon \& Tilzer 1987, Cho \& Azam 1988) and even dominates the phytoplankton carbon (PhytoC; Hessen 1985, Simon \& Tilzer 1987, Fuhrman et al. 1989, Cho \& Azam 1990). There is also recent evidence that in the oligotrophic ocean bacterial biomass contributes greatly to scattering of light which has significant implications for remote sensing (Stramski \& Kiefer 1990, Morel 1991). Further, it has been suggested that in the pelagic ocean the bacterial surface area may dominate the biotic adsorptive surface for trace metals and radionuclides and that bacteria may play an important role in biogeochemical dynamics of trace metals and radionuclides (Cho \& Azam 1988, Azam et al. 1992).

In view of the similarities and differences between lakes and oceans as phytoplankton and bacterial habitats it is important and of interest to compare their biomasses in these habitats. Despite of this only few studies have examined and compared relationships of planktonic bacteria to other important components of the trophic structure in limnetic versus marine ecosystems; mainly bacterial abundance has been compared to chlorophyll (Bird \& Kalff 1984, Cole et al. 1988).

The purpose of this paper is to synthesize the information on marine and limnetic BOC and PhytoC to examine the relationships between these major biotic carbon pools in the 2 types of environment. Much less data are, however, available on simultaneous measurements of $\mathrm{BOC}$ and PhytoC than on bacterial numbers and chlorophyll. Our analysis shows that limnetic systems relative to marine systems tend. to sustain higher bacterial biomass in relation to PhytoC although the general relationships between these carbon pools are remarkably similar in both systems.

\section{MATERIALS AND METHODS}

Biomass data of both bacteria and phytoplankton were taken from 12 studies of which 6 were marine and 6 limnetic (Table 1)
Table 1. Sources of data used for the PhytoC (phytoplankton carbon vs BOC (bacterial organic carbon) correlations, the method of PhytoC determinations, and numbers of data points

\begin{tabular}{|llr|}
\hline BOC + PhytoC & Method & No. of data \\
\hline Limnetic systems & & \\
Chrost et al. (1989) & ATP & 9 \\
Hessen (1985) & Volume & 22 \\
Pedrós-Alió \& Brock (1982) & Volume & 2 \\
Riemann et al. (1982) & Volume & 10 \\
Simon \& Tilzer (1987)/ & Volume & 51 \\
$\quad$ Simon (1987) & Volume & 10 \\
Vadstein et al. (1988) & & \\
Marine systems & Chl a a & 29 \\
Cho \& Azam (1990) & Chl a & 8 \\
Fuhrman et al. (1985) & Volume & 15 \\
Holligan et al. (1984) & Chl a & 24 \\
Lenz (1974)/ & Chl a \\
Zimmermann (1977) & Chl a \\
Salone et al. (1986) & & 2 \\
a Chleyer (1981) & & \\
PhytoC measurements & & \\
\hline
\end{tabular}

Bacterial biomass. In all studies, BOC was calculated from bacterial cell numbers determined by epifluorescence microscopy according to Zimmermann \& Meyer-Reil (1974) and Hobbie et al. (1977), and measured cell volumes and/or literature values for cell carbon. Volumes were determined from sized bacteria on enlarged epifluorescence or scanning electron micrographs. Only BOC data from Malone et al. (1986) and Cho \& Azam (1990) had been calculated with recently established $\mathrm{C}$ :cell volume ratios $(280 \mathrm{fg} \mathrm{C}$ $\mu \mathrm{m}^{-3}, 20 \mathrm{fg} C$ cell $^{-1}$; Lee \& Fuhrman 1987). In other studies in which unrealistically low $C$ : cell volume ratios had been applied bacterial cell carbon was recalculated by the equation $y=104.5 x^{0.59}$ and a C: protein ratio of 0.86 (Simon \& Azam 1989); $x$ denotes cell volume and $y$ cell protein. In the study of Fuhrman et al. (1985) in the Southern California Bight of the Pacific no cell volume data had been included. Since the mear cell volume of planktonic bacteria in this area has been reported to be $0.05 \mu^{3}$ (Fuhrman et al. 1980) BOC was calculated on this basis. Chrost et al. (1989) used ATP $\times 250$ for estimating BOC. Although the use of ATP as a biomass estimator has been criticized on the basis of variations in C:ATP ratios (Karl 1980) this study was included to test whether or not ATP-based data fit the general pattern determined on the basis of microscopic counts.

Phytoplankton biomass. Cell volumes were converted to PhytoC by using a $\mathrm{C}$ : cell volume conversion factor of either $100 \mathrm{fg} \mathrm{C} \mu \mathrm{m}^{-3}$ (Pedrós-Alıó \& Brock 1982, Riemann et al. 1982. Holligan et al. 1984, Hessen 
1985) or $150 \mathrm{fg} \mathrm{C} \mu \mathrm{m}^{-3}$ (Rocha \& Duncan 1985, recalculated data of Simon \& Tilzer 1987, Vadstein et al. 1988). Chlorophyll a (chl a) was also used for estimating PhytoC. Cho \& Azam (1990) used a C:chl a ratio of 47 which was confirmed by independent PhytoC measurements. In Lenz (1977) and Fuhrman et al. (1985) only chl a concentrations were given. For these studies PhytoC was calculated from chl a using a Cichl a ratio of 50 (Eppley et al. 1977). We are aware of the problems in estimating PhytoC from chl a concentrations due to varying C:chl ratios (Banse 1977, Eppley et al. 1977, Riemann et al. 1989). Therefore, we did statistical analysis with and without the chl a-based PhytoC data. Data of Chrost et al. (1989) were based on estimates of PhytoC as ATP $\times 276$

Statistical analysis. We did correlation analyses of all data together, of marine data and limnetic data separately. Linear correlation equations were established with least squares regression analysis after log-log transformation. After testing the data sets for lognormal distributions the data were fitted to the model $\log Y=a+b \log X$. Statistical analysis was done using an SAS statistic software package (SAS Institute, Cary, NC, USA).

\section{RESULTS}

\section{Relationships between phytoplankton and bacteria}

PhytoC data covered a range of more than 3 orders of magnitude and BOC data more than 2 orders of magnitude (Table 2, Fig. 1). Lowest marine PhytoC and $\mathrm{BOC}$ concentrations are from the Central Pacific and the Southern California Bight (Cho \& Azam 1990), and lowest limnetic values from Lake Constance, Germany (Simon \& Tilzer 1987), respectively. Highest limnetic $\mathrm{BOC}$ and PhytoC concentrations are from eutrophic lakes (Riemann et al. 1982, Vadstein et al. 1988, Chrost et al. 1989) whereas highest marine PhytoC values are from the Chesapeake Bay, USA (Malone et al. 1986). Lake Constance and the Central Pacific exhibited highest limnetic and marine BOC/PhytoC ratios, respectively (Table 2).

PhytoC concentrations varied much more than BOC concentrations, between 25 - and 74 -fold more (Table 2,

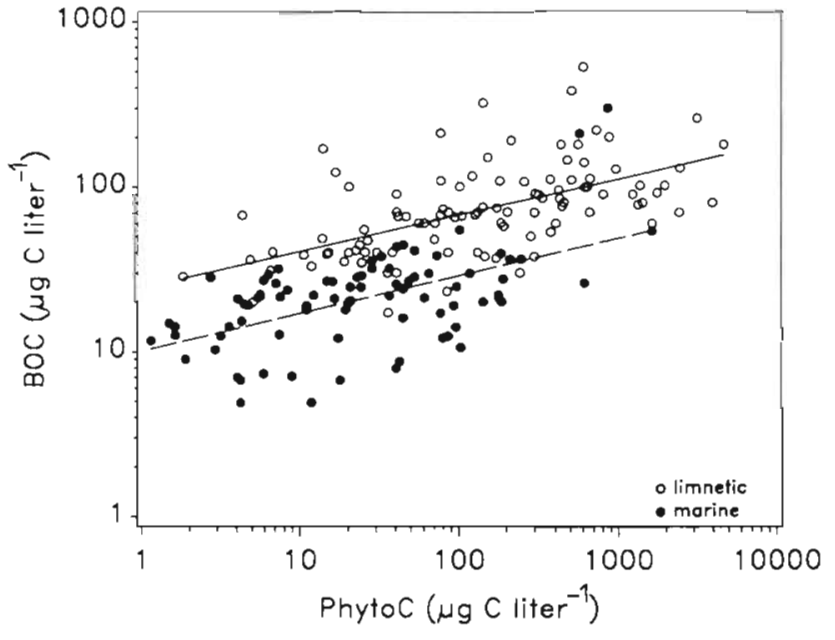

Fig. 1. Distribution patterns and calculated correlation model of log-transformed biomass (PhytoC) and bacterial biomass

(BOC) data of marine (- - ) and limnetic (-) systems

Fig. 1). Both the marine and limnetic data sets indicate a positive relationship between BOC and PhytoC with a slope substantially less than 1 and a scattering of data as in other comparable correlations (Bird \& Kalff 1984, Cole et al. 1988, Cho \& Azam 1990). The slopes of the correlations of the marine and limnetic data do not show statistically significant differences whereas the $y$-intercept of the limnetic data is significantly higher $(\mathrm{p}<0.001)$. This is the reason why the correlation of all pooled data exhibits a slope significantly higher (Table 3). The limnetic data set could have been biased by the fact that $48 \%$ of the data are from Lake Constance and exhibit features of this lake which might not be representative of other limnetic ecosystems. Analysis of the limnetic data set of BOC vs PhytoC with and without Lake Constance data showed no significant differences either in the slope or in the $y$-intercept $(\mathrm{p}<0.001)$. Further, a separate analysis of all volume-based data and including PhytoC estimates from Cho \& Azam (1990) and of all data including also chl a- and ATP-based PhytoC estimates indicates no significant difference $(p<0.001)$. This gave us confidence that including chl $a$ - and ATP-based data did not bias our analysis.

Table 2. Range and mean \pm standard deviation (SD) of $\mathrm{BOC}$ and PhytoC data $\left(\mu \mathrm{g} \mathrm{Cl}^{-1}\right)$. Abbreviations as in Table 1

\begin{tabular}{|c|c|c|c|c|}
\hline \multirow[t]{2}{*}{ Variable } & \multicolumn{2}{|c|}{ Marine } & \multicolumn{2}{|c|}{ Limnetic } \\
\hline & Range & Mean $\pm \mathrm{SD}$ & Range & Mean $\pm \mathrm{SD}$ \\
\hline $\mathrm{BOC}$ & $5-300$ & $28 \pm 38$ & $17-530$ & $89 \pm 75$ \\
\hline PhytoC & $1-1604$ & $87 \pm 215$ & $2-4600$ & $441 \pm 778$ \\
\hline BOC/PhytoC & $0.03-10.5$ & $1.91 \pm 2.44$ & $0.03-15.9$ & $1.51 \pm 2.74$ \\
\hline
\end{tabular}




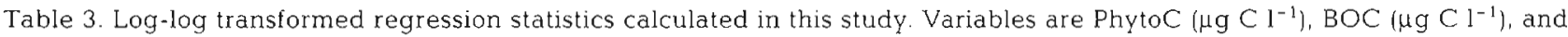
$\mathrm{BOC} / \mathrm{PhytoC}$ ( $\mathrm{n}=$ number of data points, $\mathrm{SSX}=$ sum of squares of the independent variable, $\mathrm{p}>0.0001$ ). The correction factor (CF) must be used to convert from log to arithmetic scale by the regression equation; this corrects for an inherent bias of logtransformed regressions (Sprugel 1983). Abbreviations as in Table 1

\begin{tabular}{|c|c|c|c|c|c|c|c|c|}
\hline Source & $Y, X$ & $\mathrm{n}$ & Slope & $Y$-int. & $r^{2}$ & $F$ & SSX & $\mathrm{CF}$ \\
\hline $\begin{array}{l}\text { All volume- } \\
\text { based data }\end{array}$ & $\begin{array}{l}\text { BOC } \\
\text { PhytoC }\end{array}$ & 140 & $0.300 \pm 0.03$ & $1.09 \pm 0.05$ & 0.45 & 114.5 & 11.5 & 1.58 \\
\hline $\begin{array}{l}\text { Limnetic data } \\
\text { volume-based }\end{array}$ & $\begin{array}{l}\text { BOC } \\
\text { PhytoC }\end{array}$ & 95 & $0.195 \pm 0.03$ & $1.42 \pm 0.06$ & 0.34 & 46.9 & 4.2 & 1.27 \\
\hline All data & $\begin{array}{l}\text { BOC } \\
\text { PhytoC }\end{array}$ & 186 & $0.325 \pm 0.03$ & $1.04 \pm 0.05$ & 0.46 & 155.2 & 15.2 & 1.58 \\
\hline Limnetic data & $\begin{array}{l}\text { BOC } \\
\text { Phytoc }\end{array}$ & 104 & $0.21 .9 \pm 0.03$ & $1.39 \pm 0.07$ & 0.34 & 53.1 & 5.6 & 1.34 \\
\hline Lake Constance & $\begin{array}{l}\text { BOC } \\
\text { PhytoC }\end{array}$ & 51 & $0.180 \pm 0.05$ & $1.44 \pm 0.09$ & 0.24 & 15.7 & 2.2 & 1.26 \\
\hline $\begin{array}{l}\text { Limnetic excl. } \\
\text { Lake Constance }\end{array}$ & $\begin{array}{l}\text { BOC } \\
\text { PhytoC }\end{array}$ & 53 & $0.232 \pm 0.05$ & $1.39 \pm 0.12$ & 0.30 & 21.6 & 3.5 & 1.42 \\
\hline Marine data & $\begin{array}{l}\text { BOC } \\
\text { Phytoc }\end{array}$ & 82 & $0.228 \pm 0.04$ & $1.00 \pm 0.04$ & 0.30 & 33.6 & 4.8 & 1.39 \\
\hline
\end{tabular}

The BOC/PhytoC ratios of both limnetic and marine data increased strongly with decreasing PhytoC concentrations to values as high as 4 to 16 for PhytoC concentrations $<20 \mu \mathrm{g} \mathrm{Cl}^{-1}$ (Fig. 2). Below $25 \mu \mathrm{g} \mathrm{chl} \mathrm{a} \mathrm{l}^{-1}$ the ratios were independent of chl a concentrations. BOC/PhytoC remained below 1 and for most cases

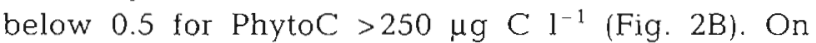
average in marine systems, $\mathrm{BOC}$ exceeded PhytoC below $25 \mu \mathrm{g}$ PhytoC $1^{-1}$ (BOC/PhytoC > 1) whereas in limnetic systems BOC exceeded PhytoC below $61 \mu \mathrm{g}$
PhytoC $1^{-1}$. We did not calculate correlations between PhytoC and $\mathrm{BOC} / \mathrm{Phy}$ toC to avoid problems with autocorrelations.

\section{DISCUSSION}

Remarkable similarities of the $\mathrm{BOC}$ vs PhytoC relationship of limnetic and marine ecosystems were shown by the statistical analysis. The general trophic relationship between phytoplankton and bacterial
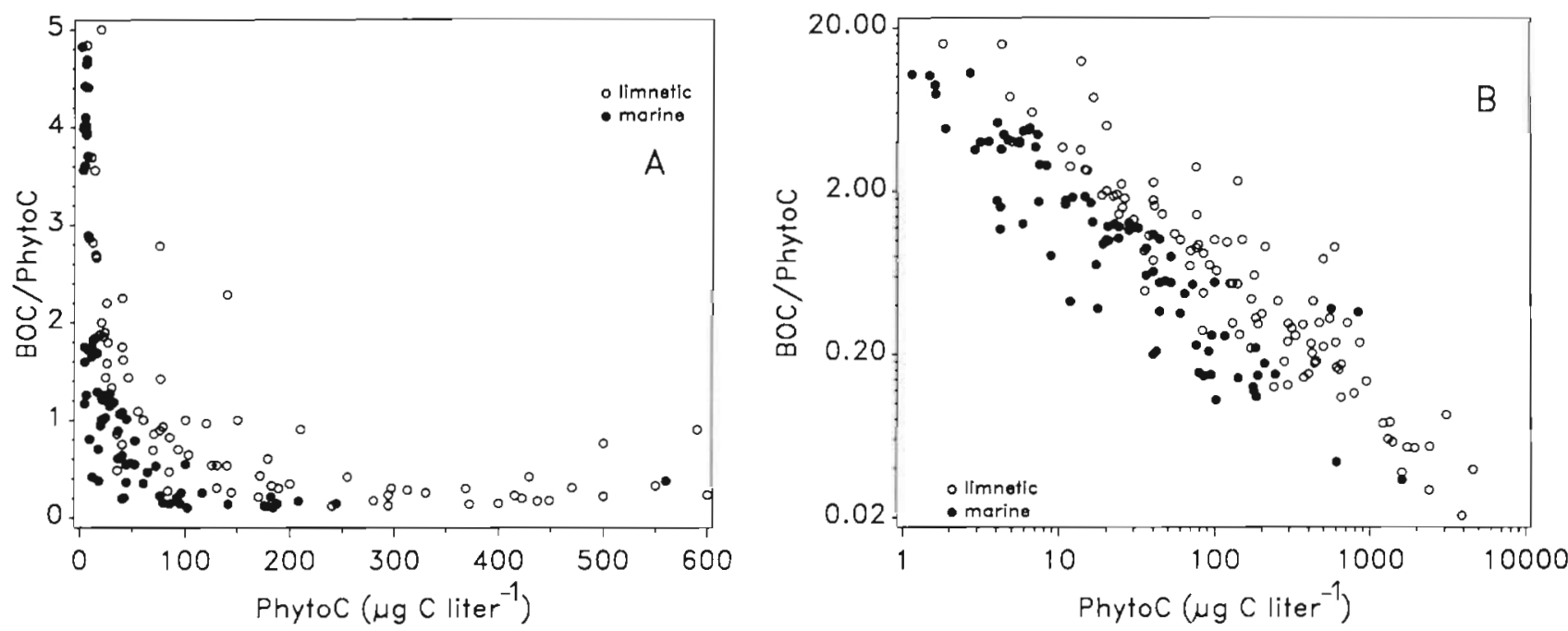

Fig. 2. Distribution of PhytoC vs BOC/PhytoC. (A) Distribution of PhytoC vs BOC/PhytoC of data $<600 \mu \mathrm{g}$ PhytoC $1^{-1}$ and BOC/PhytoC $<5$; (B) distribution of log-transformed data. Abbreviations as in Fig. 1 
biomass appears to be comparable in limnetic and marine pelagic ecosystems and supports conclusions from a literature survey on the ecological role of planktonic bacteria (Hobbie 1988) and phytoplankton (Kilham \& Hecky 1988)

Our results also confirm comparable relationships between chl a and bacterial cell numbers found in marine and limnetic waters (Linley et al. 1983, Bird \& Kalff 1984, Cole et al. 1988, Cho \& Azam 1990). Our results, based on biomass carbon and not only on abundance, however, point to some differences which have not been revealed by the above mentioned studies. The correlations we established exhibit much lower slopes than those found for chl a vs bacterial cell numbers (Bird \& Kalff 1984, Cole et al. 1988). These slopes are typically in the range of 0.6 to 0.8 whereas ours are always $<0.5$. These differences presumably also reflect that we did our calculations on the basis of carbon and took into account the cell size-dependent C:volume ratio at least for bacteria (Simon \& Azam 1989). The varying $\mathrm{C}$ :volume ratio has been shown to have a strong impact on the relationship between bacterial cell numbers and bacterial biomass vs bacterial production (Billen et al. 1990) and obviously also on correlations between bacterial numbers and biomass vs PhytoC and chl a. The fact that the slopes of our correlations are much lower than those of correlations of bacterial cell numbers vs chl a indicates that relationships on a biomass basis emphazise different aspects of the structure of pelagic food webs than cell numbers and chl $a$.

Interestingly, the $y$-intercept of the correlation equation was significantly higher in limnetic than in marine systems indicating that limnetic systems support more bacterial biomass relative to PhytoC than marine systems. This is in accordance with results of the crosssystem overview by Cole et al. (1988) on the aerial relation of bacterial production vs primary production. Although Cole et al. did not make separate statistical evaluations of these correlations their Fig. 3 indicates that from the limnetic data set 14 out of 18 points are above the regression line and 11 out of 15 points from the marine data set are below. Hence not only the correlation of $\mathrm{BOC}$ vs PhytoC but also that of aerial bacterial production vs phytoplankton primary production suggests a relatively enhanced significance of bacteria in limnetic as compared to marine systems. This may point to the fact that allochthonous substrate sources in addition to pelagic primary production fuel bacterial production in lakes and obviously lead to an enhanced biomass and production of bacteria. The relatively enhanced bacterial biomass as compared to phytoplankton biomass in limnetic vs marine systems may be also the result of further differences between both systems such as the dominance of cladocerans in lakes as compared to copepods in the ocean (Lehman 1988). Although it has been shown that some cladocerans can graze effectively on bacteria in eutrophic lakes (e.g. Pace et al. 1990) they usually tend to graze more on larger organisms such as algae and protozoans, the main consumers of bacteria. Thus, cladocerans may reduce the abundance of algae and bacterial grazers relatively more than that of bacteria. Also, the N-vs Plimitation of phytoplankton growth in the ocean and lakes (Hecky \& Kilham 1988, Baines \& Pace 1991) may have some impact on the enhanced bacterial biomass in lakes. In a literature survey Baines \& Pace (1991) found that extracellular release of photosynthates is related differently to phytoplankton primary production in limnetic and marine systems. They attribute this difference to variations between $\mathrm{P}$ - and $\mathrm{N}$-limitation in both systems. We note, however, that our analysis only includes $\mathrm{P}$-limited lakes and N-limited marine environments because, to our knowledge, respective data sets from N-limited lakes and P-limited marine systems are not available. Further, the main consumers of planktonic bacteria, protozoans, could also directly control their prey in different ways in lakes and the ocean although the limited number of comparisons with heterotrophic flagellates between lakes and marine systems has no indications for this (Weisse 1991). It could be possible that different proportions of flagellates and ciliates as bacterial and phytoplankton grazers may be reflected in relatively enhanced bacterial biomass in lakes as compared to marine waters.

Our results generalize findings of Dortch \& Packard (1989), Fuhrman et al. (1989), and Cho \& Azam (1990) to limnetic ecosystems: high and low protein/chl $a$ and $\mathrm{BOC} / \mathrm{PhytoC}$ ratios indicate fundamental differences of the food-web structure in oligotrophic and eutrophic ecosystems, e.g. the increasing dominance of heterotrophic and small organisms (heterotrophic and autotrophic picoplankton) and the microbial loop (Azam et al. 1983) in oligotrophic systems (high BOC/PhytoC). In eutrophic systems, in contrast, the grazer food chain is more important (low BOC/PhytoC) as the autotrophic and heterotrophic picoplankton becomes less important with increasing trophic state (Porter et al. 1988). Mesotrophic ecosystems with large seasonal variations such as Lake Constance cover oligotrophic and eutrophic situations during the course of the seasons with a fairly variable foodweb structure (Weisse et al. 1990, Geller et al. 1991, Weisse 1991).

Recently it has been shown that planktonic bacteria can contribute substantially to light scattering in marine waters (Spinrad et al. 1989, Stramski \& Kiefer 1990, Morel 1991). Stramski \& Kiefer and Morel also estimated the consequences of their experimental findings for biooptical properties and remote sensing. They conclude that in particular in oligotrophic waters with 
low phytoplankton biomass $\left(<1 \mathrm{mg}\right.$ chl a $\mathrm{m}^{-3}$ ) bacteria can contribute significantly to backscattering of light. They also showed that the size distribution of bacteria is important in backscattering properties of the total bacterioplankton. If larger bacteria, e.g. $>0.7 \mu \mathrm{m}$, contribute substantially to total bacterial abundance and their abundance is comparable to or greater than that of other microbial organisms they may be a major source of backscattering of light (Morel 1991). In the oligotrophic ocean and even in mesotrophic waters the average size of bacteria is small and fairly constant (ca 0.05 to $0.07 \mu \mathrm{m}^{3}$, equivalent spherical diameter $0.4 \mu \mathrm{m}_{i}$ Lee \& Fuhrman 1987, Simon 1987). It has been shown, however, that in Lake Constance at times when bacteria dominate the microbial biomass bacterial cells in the size of 1.0 to $3.0 \mu \mathrm{m}$ can comprise between 5 and $20 \%$ of total bacterial abundance (Simon 1987). These relatively large bacteria in the size and abundance of autotrophic picoplankton cells thus may have a major impact on light scattering properties (Morel 1991) because even $5 \%$ of bacteria (ca $5 \times 10^{4} \mathrm{ml}^{-1}$ ) would numerically be a large component of the 1 to $3 \mu \mathrm{m}$ particle fraction. Therefore, the significance of bacteria for light scattering in remote sensing studies should be reconsidered, in the ocean as well as in large meso- and oligotrophic lakes.

Since in oligotrophic lakes, as in the ocean, bacterial biomass dominates the phytoplankton biomass this has implications for the cycling of trace metals and radionuclides in lakes. The dominant adsorptive surface area of bacteria suggests that a major fraction of these materials interacting with organic surfaces (as well as surface-reactive pollutants) would enter the microbial loop via bacteria rather than the grazer food chain via phytoplankton (Azam 1984, Cho \& Azam 1988). Studies from Lake Zürich (Santschi et al. 1988) and Lake Constance (Robbins et al. 1992) show that the epilimnetic removal of ${ }^{103} \mathrm{Ru}$, an anionic radionuclide from the Chernobyl reactor accident, was correlated with the sedimentation of particulate organic matter (POM). Robbins et al. propose that dissolved ${ }^{103} \mathrm{Ru}$ enters the POM pool via transfer to organic colloids, aggregation, and further into the plankton. In this process, but also with other radionuclides and trace metals behaving like ${ }^{103} \mathrm{Ru}$, bacteria could play a key role because of their high reactive surface and because they are the most important organisms transforming dissolved organic matter into POM. Also, the efficient mineralization of materials by the microbial loop could strongly influence the distribution patterns of surface-reactive pollutants. Seasonal changes in the trophic status of pelagic ecosystems (with respect to BOC/PhytoC) which occur predominantly in mesotrophic lakes could thus fundamentally change the pathways of transfer and transformation of trace metals and pollutants.
Are the relationships we found and hence our conclusions based on reliable assumptions in estimating the carbon pools or are they affected by methodological shortcomings and artefacts? Although most methodological problems which could potentially affect our findings are discussed in Cho \& Azam (1990) we want to re-affirm this and add certain points. The relationships between PhytoC and BOC we established are the first in which a varying $C$ : cell volume ratio of bacterial biomass (Simon \& Azam 1989) has been used. Some data included in our analysis (Malone et al. 1986, Cho \& Azam 1990) applied a constant amount of C per cell for cells $<0.07 \mu^{3}$ whereas the other data were recalculated assuming a decreasing amount of $\mathrm{C}$ per unit cell volume with increasing cell size for all cell sizes. Since the difference of the 2 calculations for the smallest cell sizes included is $<25 \%$, our general results are not affected. If the ATP-based BOC estimates (Chrost et al. 1989) which accounted for $9 \%$ of the limnetic data even include some significant errors this would not influence the general results either.

The general problems of estimating PhytoC from chl a, cell volume, or POC have been discussed elsewhere (Banse 1977, Eppley et al. 1977, Rocha \& Duncan 1985, Riemann et al. 1989, Cho \& Azam 1990). A conclusion from these studies is that cell volume-based PhytoC estimates are most reliable although $\mathrm{C}$ : cell volume conversion factors can also vary depending on the species and its physiological state (Rocha \& Duncan 1985, Riemann et al. 1989). In our BOC vs PhytoC analysis $75 \%$ of all data and $91 \%$ of the limnetic data are cell volume-based. Even if the conversion factors applied are not totally accurate this should not affect our general conclusions. The fact that we used $150 \mathrm{mg} \mathrm{C} \mathrm{ml}^{-1}$ as compared to $100 \mathrm{mg} \mathrm{C} \mathrm{ml} \mathrm{m}^{-1}$ for some limnetic PhytoC data (see 'Materials and methods') even smooths the differences between limnetic and marine data by relatively enhancing some limnetic PhytoC values. We wish to point out, however, that we did not take into account a cell size-dependent $\mathrm{C}$ : volume ratio for varying sizes of algae (Mullin et al. 1966). For calculating PhytoC from chl a we either adopted the C: chl a ratio of the reference (Malone et al. 1986) or tried to use the most appropriate ratio. Even though the $C$ :chl a ratio can exhibit wide variations (Eppley et al. 1977, Riemann et al. 1989) an imprecise ratio applied would not change the general conclusions of our results because the major part of the data is cell volumebased. The same conclusion as for chl a holds true for the use of ATP-based PhytoC data (Chrost et al. 1989).

In conclusion, we have shown that relationships of $\mathrm{BOC}$ to PhytoC in limnetic and marine ecosystems exhibit remarkable similarities but that limnetic systems can sustain more BOC relative to PhytoC than marine systems. These findings point to interesting 
functional similarities between the 2 systems but also to principal differences concerning the substrate sources for the bacterioplankton, e.g. allochthonous vs autochthonous sources. We suggest that bacteria in lakes, as in oceans, may significantly influence the spatial and temporal variability in material (and pollutant) cycling pathways

Acknowledgements. This work was supported by the Deutsche Forschungsgemeinschaft-sponsored Special Collaborative Program SFB-248 'Cycling of Matter in Lake Constance and by grants from Basic Science Research Institute Program, Ministery of Education, Korea, and US NSF and DOE. We thank U. Gaedke and R. Heusel for helpful advice in the statistical analysis and 3 anonymous reviewers for helpful suggestions on the manuscript.

\section{LITERATURE CITED}

Azam, F. (1984). The radioecological role of marine bacterioplankton. In: Bonnyns-van Gelder, E., Kirchmann, R. (eds.) Role of microorganisms on the behaviour of radionuclides in aquatic and terrestrial systems and their transfer to man. International Union of Radioecologists, Commission of the European Communities, Brussels, p. 2-7

Azam, F., Fenchel, T., Field, J. G., Gray, J. S., Meyer-Reil, L. A., Thingstad, F. (1983). The ecological role of watercolumn microbes in the sea. Mar. Ecol. Prog. Ser. 10: $257-263$

Azam, F., Smith, D. C., Carlucci, A. F. (1992). Bacterial transformation and transport of organic matter in the Southern California Bight. Prog. Oceanogr. (in press)

Baines, S. B., Pace, M. L. (1991). The production of dissolved organic matter by phytoplankton and its importance to bacteria: patterns across marine and freshwater systems. Limnol. Oceanogr. 36: 1078-1090

Banse, K. (1977). Determining the carbon-to-chlorophyll ratio of natural phytoplankton. Mar. Biol. 41: 377-388

Billen, G., Servais, P., Becquefort, S. (1990). Dynamics of bacterioplankton in oligotrophic and eutrophic aquatic environments: bottom-up or top-down control? Hydrobiologia 207: $37-42$

Bird, D. F., Kalff, J. (1984). Empirical relationships between bacterial abundance and chlorophyll concentration in fresh and marine waters. Can. J. Fish. Aquat. Sci. 41. $1015-1023$

Cho, B. C., Azam, F. (1988). Major role of bacteria in biogeochemical fluxes in the ocean's interior. Nature 332: $441-443$

Cho, B. C., Azam, F. (1990). Biogeochemical significance of bacterial biomass in the ocean's euphotic zone. Mar. Ecol. Prog. Ser. 63: 253-259

Chrost, R. J., Münster, U., Rai, H., Albrecht, D., Witzel, K. P., Overbeck, J. (1989). Photosynthetic production and exoenzymatic degradation of organic matter in the euphotic zone of a eutrophic lake. J. Plankton Res. 11: 223-242

Cole, J. J., Findlay, S., Pace, M. L. (1988). Bacterial production in fresh and saltwater ecosystems: a cross-system overview. Mar. Ecol. Prog. Ser. 43: 1-10

Dodds, W. K., Priscu, J. C., Ellis, B. K. (1991). Seasonal uptake and regeneration of inorganic nitrogen and phosphorus in a large oligotrophic lake: size-fractionation and antibiotic treatment. J. Plankton Res. 13: 1339-1358
Dortch, Q., Packard, T T. (1989). Differences in biomass structure between oligotrophic and eutrophic marine ecosystems. Deep Sea Res. 36: 223-240

Eppley, R. W., Harrison, W. G., Chisholm, S. W., Stewart, E. (1977). Particulate organic matter in surface waters off Southern California and in relation to phytoplankton. J. mar. Res. 35: 671-696

Fuhrman, J. A., Ammerman, J. W., Azam, F (1980) Bacterioplankton in the coastal euphotic zone: distribution, activity, and possible relation with phytoplankton. Mar. Biol. 60: 201-207

Fuhrman, J. A., Eppley, R. W., Hagström, A., Azam, F. (1985). Diel variation in bacterioplankton, phytoplankton, and related parameters in the Southern California Bight. Mar. Ecol. Prog. Ser. 27: 9-20

Fuhrman, J. A., Sleeter, T. D., Carlson, C. A., Proctor, L. M. (1989). Dominance of bacterial biomass in the Sargasso Sea and its ecological implications. Mar. Ecol. Prog. Ser. 57: $207-217$

Geller, W., Berberovic, R., Gaedke, U., Müller, H., Pauli, H. R., Tilzer, M. M., Weisse, T. (1991). Relations among the components of autotrophic and heterotrophic plankton during the seasonal cycle 1987 in Lake Constance. Verh. int. Verein. Limnol. 24: 831-836

Hecky, R. E., Kilham, P. (1988). Nutrient limitation of phytoplankton in freshwaters and marine environments: a review of recent evidence on the effect of enrichment. Limnol. Oceanogr. 33: 796-822

Hessen, D. O. (1985). The relation between bacterial carbon and dissolved humic compounds in oligotrophic lakes. FEMS Microbiol. Ecol. 31: 215-223

Hobbie, J. E. (1988). A comparison of the ecology of planktonic bacteria in fresh and salt waters. Limnol. Oceanogr. 33: $750-764$

Hobbie, J. E., Daley, R. J., Jasper, S. (1977). Use of nuclepore filters for counting bacteria by fluorescence microscopy. Appl. environ. Microbiol. 33: 1225-1228

Holligan, P. M., Harris, R. P., Newell, R. C., Harbour, D. S., Head, R. N., Linley, E. A. S., Lucas, M. I., Tranter, P. R. G., Weekley, C. M. (1984). Vertical distribution and partitioning of organic carbon in mixed, frontal and stratified waters of the English Channel. Mar. Ecol. Prog. Ser. 14: $111-127$

Karl, D. M. (1980). Cellular nucleotid measurements and applications in microbial ecology. Microbiol. Rev. 44: $739-796$

Kilham, P., Hecky, R. E. (1988). Comparative ecology of marine and freshwater phytoplankton. Limnol. Oceanogr 33: 776-795

Krom, M. D., Brenner, S., Kress, N., Neori, A., Gordon, L. I. (1992). Nutrient dynamics and new production in a warm core eddy from the Eastern Mediterranean Sea. Deep Sea Res. 39: 467-480

Lee, S., Fuhrman, J. A. (1987). Relationship between biovolume and biomass of naturally derived marine bacterioplankton. Appl. environ. Microbiol. 53: 1298-1303

Lehman, J. T (1988). Ecological principles affecting community structure and secondary production by zooplankton in marine and freshwater environments. Limnol. Oceanogr. 33: 931-945

Lenz, J. (1977). Seston and its main components. In: Rheinheimer, G. (ed.) Microbial ecology of a brackish water environment. Springer, New York, p. 37-60

Linley, E. A. S., Newell, R. C., Lucas, M. I. (1983). Quantitative relationships between phytoplankton, bacteria and heterotrophic microflagellates in shelf waters. Mar. Ecol. Prog. Ser. 12:77-89 
Malone, T C., Kemp, W. M., Ducklow, H. W., Boynton, W. R., Tuttle, J. H., Jonas, R. B. (1986). Lateral variation in the production and fate of phytoplankton in a partially stratified estuary. Mar. Ecol. Prog. Ser. 32: $149-160$

Morel, A. (1991). Optics of marine particles and marine optics. In: Demers, S. (ed.) Particle analysis in oceanography. Springer, Berlin, p. 141-188

Mullin, M., Sloan, P., Eppley, R. W. (1966). Relationship between carbon content, cell volume, and area in phytoplankton. Limnol. Oceanogr. 11: 307-311

Pace, M. L., McManus, G. B., Findlay, S. E. G. (1990). Planktonic community structure determines the fate of bacterial production in a temperate lake. Limnol. Oceanogr. 35: 795-808

Pedrós-Alió, C., Brock, T. D. (1982). Assessing biomass and production of bacteria in eutrophic Lake Mendota, Wisconsin. Appl, environ. Microbiol. 44: 203-218

Porter, K. G., Paerl. H. W., Hodson. R. E., Pace, M. L., Priscu, J., Riemann, B., Scavia, D., Stockner, J. (1988). Microbial interactions in lake food webs. In: Carpenter, S. R. (ed.) Complex interactions in lake communities. Springer, New York, p. 209-227

Riemann, B., Simonsen, P., Stensgaard, L. (1989). The carbon and chlorophyll content of phytoplankton from various nutrient regimes. J. Plankton Res. 11: 1037-1045

Riemann, B., Søndergaard, M., Schierup, H. H., Bosselmann, S., Christensen, G., Hansen, J., Nielsen, B. (1982). Carbon metabolism during a spring diatom bloom in the eutrophic Lake Mossø. Int. Revue ges. Hydrobiol. 67: 145-185

Robbins, J. A., Lindner, G., Pfeiffer, W., Kleiner, L., Stabel, H. H., Frenzel, P. (1992). Epilimnetic scavenging of Chernobyl radionuclides in Lake Constance. Geochim. Cosmochim. Acta 56: 2339-2361

Rocha, O., Duncan, A. (1985). The relationship between cell carbon and cell volume in freshwater algal species used in zooplankton studies. J. Plankton Res. 7: 279-294

Santschi, P. H., Bollhalder, S., Farremkothem, M., Lück, A., Zingg, S., Sturm, M. (1988). Chernobyl radionuclides in the environment: tracers for the tight coupling of atmospheric, terrestrial, and aquatic geochemical processes.

This article was submitted to the editor
Environ. Sci. Technol. 22: 510-516

Schleyer, M. H. (1981). Microorganisms and detritus in the water column of a subtidal reef of Natal. Mar. Ecol. Prog. Ser. $4: 307-320$

Simon, M. (1987). Biomass and production of small and large free-living and attached bacteria in Lake Constance. Limnol. Oceanogr. 32: 591-607

Simon, M., Azam, F. (1989). Protein content and protein synthesis rates of planktonic marine bacteria. Mar. Ecol. Prog. Ser. 51: 201-213

Simon, M., Tilzer, M. M. (1987). Bacterial response to seasonal changes in primary production and phytoplankton biomass in Lake Constance. J. Plankton Res. 9: 535-552

Spinrad, R. W., Glover, H., Ward, B., Codispoti, L. A., Kullenberg, G. (1989). Suspended particle and bacterial maxima in Peruvian coastal waters during a cold water anomaly. Deep Sea Res. 36: 715-733

Sprugel, D. G. (1983). Correcting for bias in log-transformed allometric equations. Ecology 64: 209-210

Stramski, D., Kiefer, D. A. (1990). Optical properties of marine bacteria. In: Spinrad, R. W. (ed.) Ocean Optics X, 1302: 250-268. Society of Photo-Optical Instrumentation Engineers, Bellingham

Vadstein, O., Jensen, A., Olsen, Y., Reinertsen, H. (1988). Growth and phosphorus status of limnetic phytoplankton and bacteria. Limnol. Oceanogr. 33: 489-503

Weisse, T. (1991). The microbial food web and its sensitivity to eutrophication and contaminant enrichment: a crosssystem overview. Int. Revue ges. Hydrobiol. 76: 327-337

Weisse, T., Müller, H., Pinto-Coelho, R. M., Schweizer, A., Springmann, D., Baldringer, G. (1990). Response of the microbial loop to the phytoplankton spring bloom in a large prealpine lake. Limnol. Oceanogr. 35: 781-794

Zimmermann, R. (1977). Estimation of bacterial number and biomass by epifluorescence microscopy and scanning electron microscopy. In: Rheinheimer, G. (ed.) Microbial ecology of a brackish water environment. Springer, New York, p. 103-120

Zimmermann, R., Meyer-Reil, L. A. (1974). A new method for fluorescence staining of bacterial populations on membrane filters. Kieler Meeresforsch. 30: 24-26

Manuscript first received: March 31, 1992

Revised version accepted: August 14, 1992 